\title{
The Global State of Genome Editing
}

\author{
Geoffrey H. Siwo \\ Center for Research Computing, Eck Institute for Global Health, Department of Biological Sciences, \\ University of Notre Dame, IN, 46556, USA \\ Correspondence: gsiwo@nd.edu
}

\begin{abstract}
Genome editing technologies hold great promise in fundamental biomedical research, development of treatments for animal and plant diseases, and engineering biological organisms for food and industrial applications. Therefore, a global understanding of the growth of the field is needed to identify challenges, opportunities and biases that could shape the impact of the technology. To address this, this work applies automated literature mining of scientific publications on genome editing in the past year to infer research trends in 2 key genome editing technologies- CRISPR/Cas systems and TALENs. The study finds that genome editing research is disproportionately distributed between and within countries, with researchers in the US and China accounting for 50\% of authors in the field whereas countries across Africa are underrepresented. Furthermore, genome editing research is also disproportionately being explored on diseases such as cancer, Duchene Muscular Dystrophy, sickle cell disease and malaria. Gender biases are also evident in genome editing research with considerably fewer women as principal investigators. The results of this study suggest that automated mining of scientific literature could help identify biases in genome editing research as a means to mitigate future inequalities and tap the full potential of the technology.
\end{abstract}

\section{Introduction}

Genome editing is one of the fastest growing areas in biomedical research and has a high potential in revolutionizing fundamental biological research, engineering of organisms for synthetic applications and eventually clinical medicine [1]. Given the potential societal impact of genome editing technologies, the ethical issues it raises and the economic potential through biomedical applications as well as creation of new jobs, a global understanding of the growth of the field is needed to identify challenges, opportunities and biases that could shape the impact of the technology $[2,3]$.

Several approaches to genome editing exist- meganucleases [4], Zinc Finger Nucleases (ZFNs) [5], TALENs (Transcription Activator-Like Nucleases) and CRISPR/Cas systems (Clustered Regularly Interspaced Short Palindromic Repeats/CRISPR associated protein) [6]. However, TALENs and the RNA-guided programmable endonucleases -CRISPR/Cas systems- have become the most popular due to the relative ease with which they can be programmed to target DNA in a sequence-specific manner. As genome editing is still in its early days, there may be 
opportunities to direct its development in a way that maximizes the power of the technology equitably and in a socially responsible manner. In this work, we apply automated mining of abstracts of genome editing publications in 2017 and part of 2018, focusing on the 2 main genome editing technologies- CRISPR/Cas and TALENs to infer the global distribution of genome editing research as a first step to identify emerging biases.

\section{Results}

\section{General publication trends in genome editing}

To obtain scientific publications on genome editing by CRISPR/Cas systems and TALENs, an automated search on PubMed followed by a download of abstracts was performed in the $\mathrm{R}$ programming language as described in the Methods section. In 2017, there were 1521 papers directly mentioning CRISPR and genome editing in their abstracts compared to 684 papers for 2018 (up to May 21 ${ }^{\text {st }}$ 2018). These studies were published across 529 and 349 scientific journals in 2017 and 2018, respectively. In contrast for TALENs based genome editing, there were 146 articles in 2017 as compared to 46 articles in 2018 across 103 and 36 journals, respectively.

The top 5 journals for CRISPR genome editing publications were Scientific Reports (81 articles, open access), Methods in Molecular Biology (49, subscription), Nature Communications (32, open access), Nature (30, subscription) and PLoS ONE (27, open access) in 2017. The top journals in 2018 were Methods in Molecular Biology (24, subscription), Scientific Reports (15, open access), ACS Chemical Biology (13, subscription), Nature Communications (13, open access) and PLoS ONE (13, open access). For TALENs, the top journals were Methods in Molecular Biology (12 articles, subscription), Frontiers in Plant Science (6, subscription), PLoS ONE (5, open access), Developmental Biology (4, subscription), Molecular Therapy- Methods \& Clinical Development (4, subscription). A complete table of the number of articles per journal is available in the Supplementary Table 1 and 2. There was a positive correlation between the number of articles published on CRISPR and TALENs (Spearman correlation, $r=0.53, P=1.5 \mathrm{e}-08$ ). A small fraction of journals accounted for a large proportion of most genome editing articles (Figure 1). Specifically, the top 50 journals for CRISPR genome editing in 2017 accounted for $48 \%$ of the articles (719 out 1521 articles). These journals constitute only $9.4 \%$ (50 out of 529 journals) of the total journals that published at least one article on CRISPR genome editing. A similar observation was made for publications on TALENs where $64 \%$ of the articles (93 out of 146 articles) were accounted for by 49\% of the journals (50 out of 103 journals). These results show that genome editing publications are disproportionately distributed in a few journals including journals that require a subscription. 
A

Proc. Natl. Acad. Sci. U.S.A. Front Plant Sci ACS Synth Biol Mol. Cell Nat. Biotechnol. Nucleic Acids Res. Plant Biotechnol. J. Prog Mol Biol Transl Sci Mol Ther Nucleic Acids Oncotarget Methods

Sheng Wu Gong Cheng Xue Bao

Mol. Ther. Adv. Exp. Med. Biol. Science

$\begin{array}{llllllllll}0 & 10 & 20 & 30 & 40 & 50 & 60 & 70 & 80 & 90\end{array}$

Number of articles

B

Methods Mol. Biol. Front Plant Sci PLOS ONE Dev. Biol. Mol Ther Methods Clin Dev Prog Mol Biol Transl Sci Crit. Rev. Biotechnol.

Hum. Gene Ther. ACS Synth Biol Cell Biosci Cell. Mol. Life Sci. Front Mol Neurosci J. Biotechnol. Nat Protoc Nucleic Acids Res. Sci China Life Sci Sci Rep

Sheng Wu Gong Cheng Xue Bao

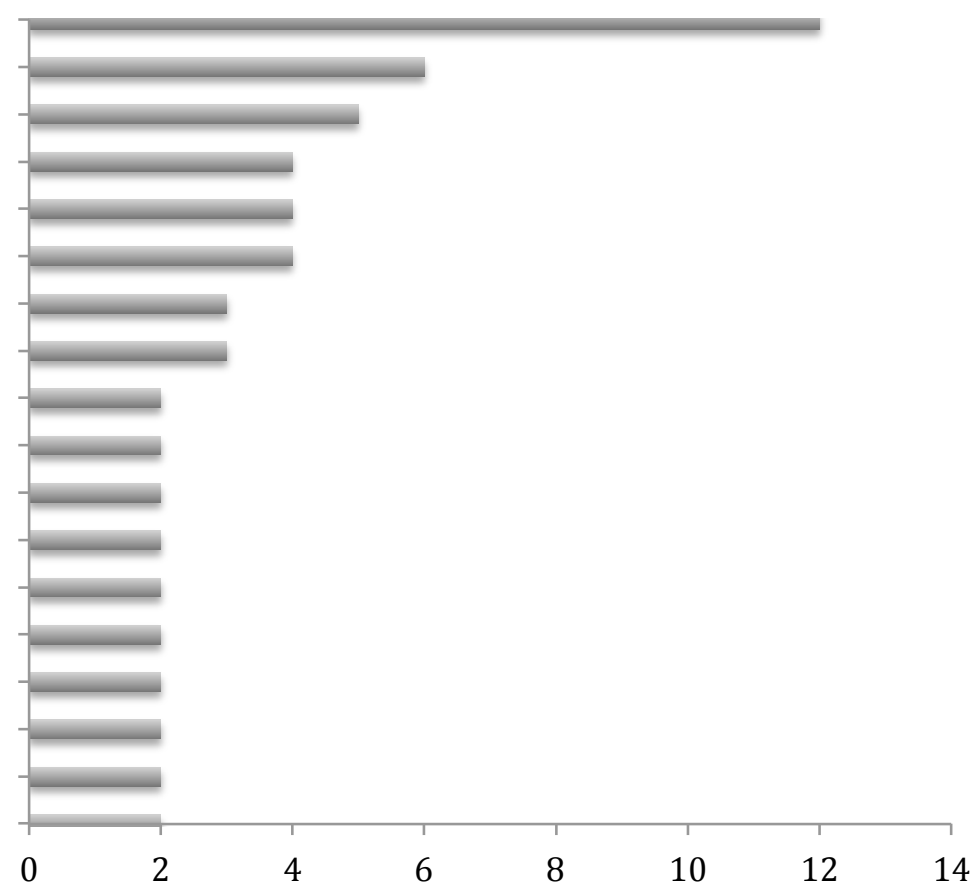

Number of articles

Figure 1: Number of articles on genome editing involving CRISPR/Cas (A) or TALENs (B) based on the top 50 journals. Journals are ranked by the number of 
articles mentioning CRISPR genome editing (A) or TALENs genome editing (B) in their abstracts.

\section{Geographical distribution of genome editing studies}

To provide an assessment of the global network of scientists performing genome editing research and publishing their findings, author names were extracted from the downloaded abstracts for the year 2017. In order to identify unique authors, the first names and last names of each author were combined. This resulted in 8,528 unique authors on CRISPR genome editing and 745 authors for TALENs. For CRISPR, the top authors included Feng Zhang (Harvard University, USA; 15 articles), Kim-Jin Soo (Seoul National University, Korea; 15 articles), Gao Caixia (Chinese Academy of Sciences, China; 11 articles), Jennifer Doudna (UC Berkley, USA; 9 articles), Gersbach Charles (Duke University, USA; 9 articles) and Musunuru Kiran (University of Pennsylvannia, USA; 9 articles). Notably, Feng Zhang and Jennifer Doudna who are both central pioneers in CRISPR based genome editing technologies feature in the top authors. In comparison, top authors for TALENs were Sakuma Tetsushi (Hiroshima University, Japan; 5 articles), Yamamoto Takashi (Hiroshima University, Japan; 5 articles), Cathomen Toni (University of Freiberg, Germany; 4 articles) and Mussolino Claudio (University of Freiberg, Germany; 4 articles). It is interesting to note that the top authors for CRISPR genome editing are mainly from the US but they do not feature among the top authors for TALENs. The top 50 authors account for about $20 \%$ (301 out of 1521) of CRISPR genome editing publications and $60 \%$ of TALENs publications (88 out of 146). The top authors and institutional affiliations are provided in Supplementary Table 3 and 4.

A

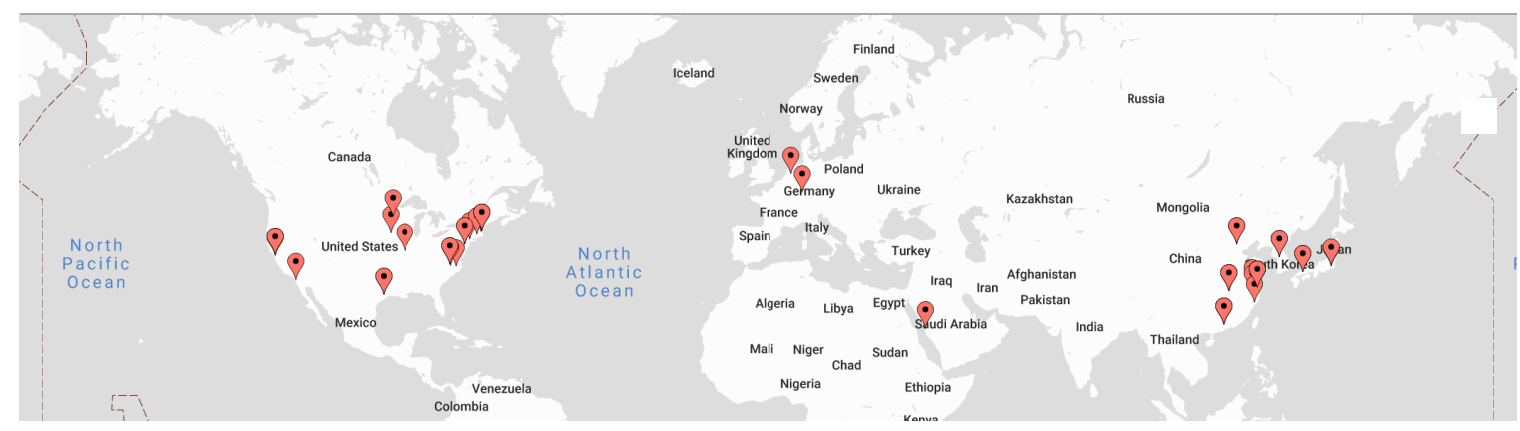


B

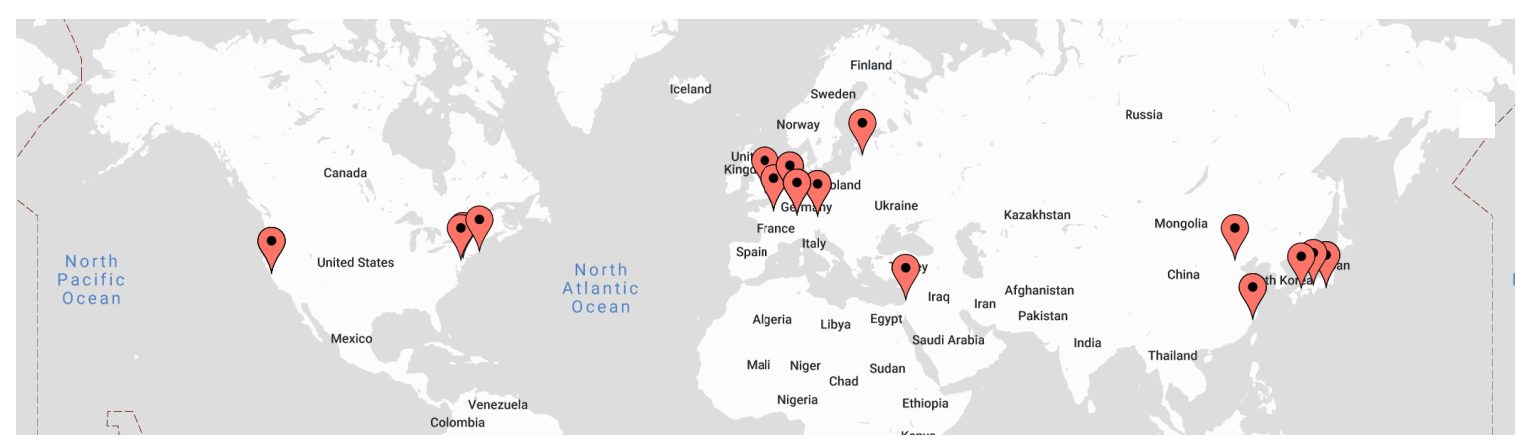

Figure 2: The global distribution of the top 50 authors based on the number of articles published by each author on CRISPR (A) or TALENs (B) based genome editing in 2017.

US and China account for approximately $50 \%$ of all 8,528 authors for CRISPR genome editing studies in 2017 with 2342 and 2140 authors, respectively. These two countries also lead in terms of the number of authors publishing on TALENs genome editing. Notably, while US leads on CRISPR, China leads on TALENs. The top 20 countries based on the number of authors on CRISPR or TALENs genome editing are provided in Figure 3.

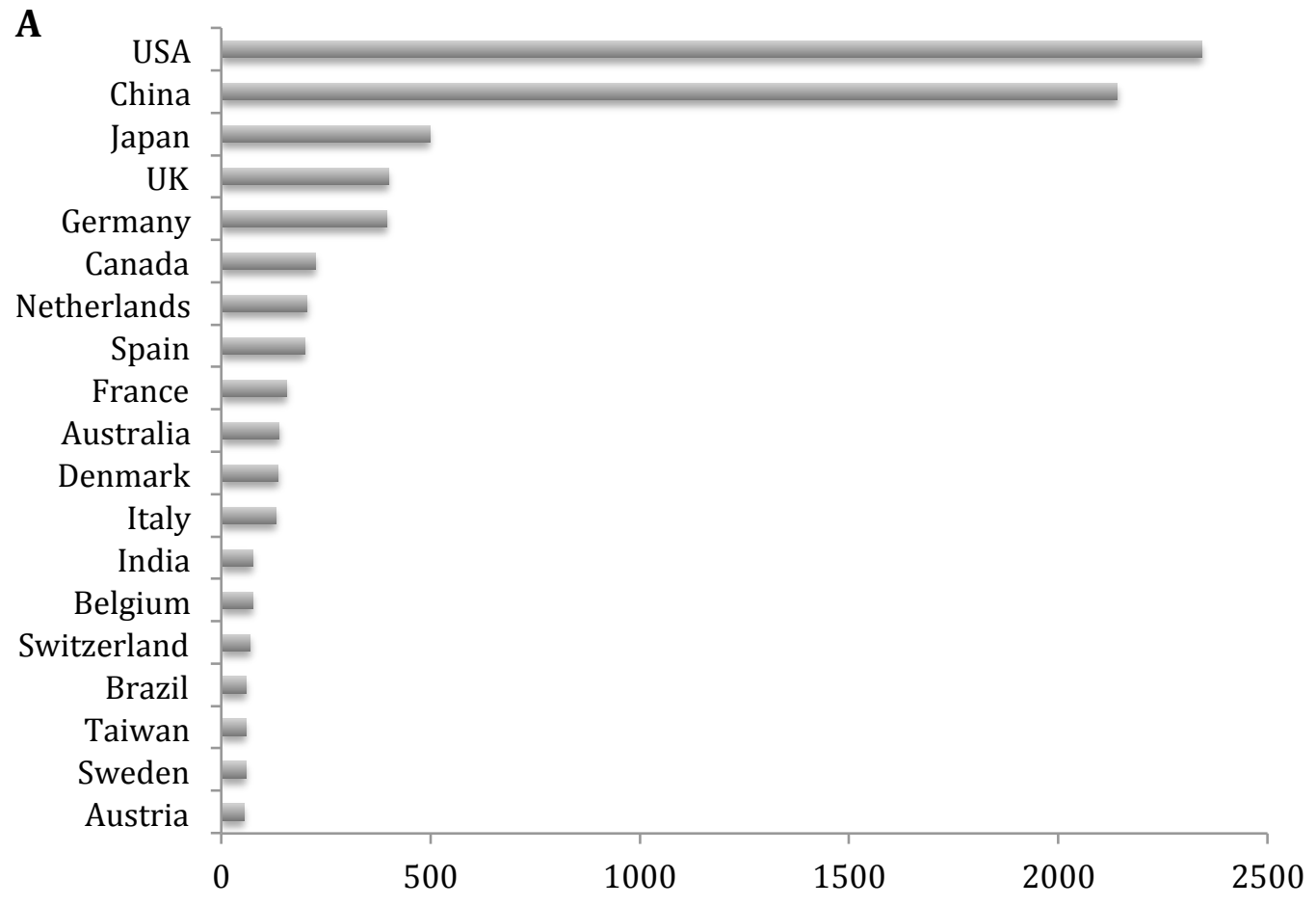

Number of articles 


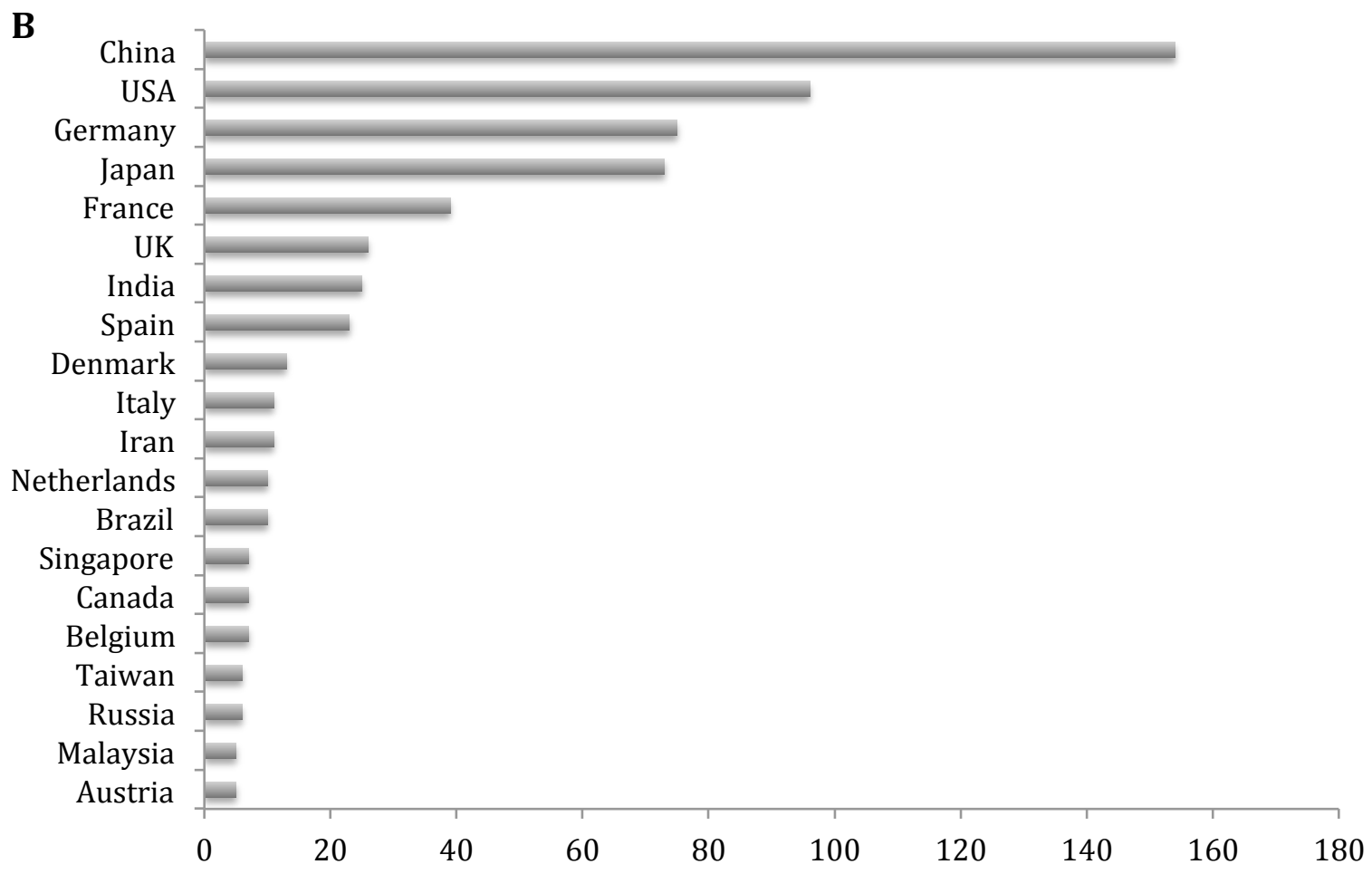

Number of articles

Figure 3: A ranking of the top 20 countries based on number of authors affiliated with institutions in those countries. (A) CRISPR based genome editing and (B) TALENs based genome editing.

\section{Gender composition of authors in genome editing studies}

Gender diversity is critical in advancing scientific discovery and overcoming health disparities. Yet, women are underrepresented in multiple fields of science and technology $[7,8]$. Assessing gender diversity in emerging areas of technology could provide opportunities for addressing disparities before they become entrenched in society. To estimate the gender representation of male and female authors, the first names of authors was used to assign gender based on data from the US Social Security Administration baby names in the R package 'gender'. In 2017 for CRISPR genome editing, $43 \%$ of first authors were females while $57 \%$ were males. In contrast, when examining the last authors, conventionally the principal investigators, only $26 \%$ were females and the rest (74\%) were males. The disparity between male and female authors was slightly lower when considering all authors of CRISPR genome editing papers irrespective of their positions in the author list ( $40 \%$ were females and $60 \%$ males). Authorship of papers on TALENs showed similar patterns: females were $42 \%$ of first authors, $28 \%$ of last authors and $40 \%$ of all authors. These results suggest that pre-existing gender biases in science and technology could be carried over to emerging technologies like genome editing. 
Table 1: Gender composition of authors in genome editing (2017) based on about $50 \%$ of first names where gender could be assigned. (A) CRISPR and (B) TALENs based genome editing.

A

\begin{tabular}{llll}
\hline Gender & $\begin{array}{l}\text { First Authors } \\
\text { (\%) }\end{array}$ & $\begin{array}{l}\text { Last Authors } \\
\text { (\%) }\end{array}$ & $\begin{array}{l}\text { All Authors } \\
\text { (\%) }\end{array}$ \\
\hline Female & $271(43 \%)$ & $143(26 \%)$ & $1600(40 \%)$ \\
Males & $352(57 \%)$ & $401(74 \%)$ & $2419(60 \%)$ \\
\hline
\end{tabular}

B

\begin{tabular}{llll}
\hline Gender & $\begin{array}{l}\text { First Authors } \\
\text { (\%) }\end{array}$ & $\begin{array}{l}\text { Last Authors } \\
\text { (\%) }\end{array}$ & $\begin{array}{l}\text { All Authors } \\
\text { (\%) }\end{array}$ \\
\hline Female & $25(42 \%)$ & $17(28 \%)$ & $139(40 \%)$ \\
Males & $34(58 \%)$ & $44(72 \%)$ & $209(60 \%)$ \\
\hline
\end{tabular}

\section{Genes, diseases and species targeted by genome editing studies}

Identification of genes and diseases being investigated by genome editing technologies could help in the assessment of potential early clinical applications of the technology and highlight areas that may require new investment. Screening of the downloaded abstracts for gene names led to the retrieval of genes that are the focus of various genome editing studies. Genes were then ranked by the number of genome editing studies in which they appeared in the abstracts. The dystrophin gene (DMD) was the most frequently studied gene using CRISPR, followed by several cancer associated genes including P53 $[9,10]$, Cystic Fibrosis Transmembrane Conductance (CFTR) gene [11, 12], CXCR4- an HIV-1 entry coreceptor $[13,14]$ - and the hemoglobin $B$ gene (HBB) important in sickle cell anemia and other hemoglobinopathies (Table 2) [15, 16]. CD4, an HIV-1 receptor [17] was the most studied gene for TALENs genome editing although there were only 2 articles.

Another alternative approach for identifying diseases being targeted by genome editing technologies is using named entity recognition to extract disease names directly from abstracts. When this approach was applied to screen abstracts, the top diseases for CRISPR genome editing were cancer/tumor/carcinoma (355 articles), Duchenne Muscular Dystrophy (DMD, 24), malaria (14), HIV/AIDS (18) and hepatitis B/C virus (13). On the other hand, top diseases for TALENs were cardiovascular diseases (9 articles), HIV/AIDS (9), hepatitis B/C virus (8) and hemoglobinopathies ( 4 articles). 
Table 2: Top genes and diseases associated with CRISPR genome editing studies in 2017.

\begin{tabular}{|c|c|c|}
\hline Gene & Count & Disease \\
\hline Dystrophin/DMD & 17 & Duchenne Muscular Dystrophy $[18,19]$ \\
\hline P53/TP53 & 15 & Cancer $[9,20,10]$ \\
\hline AAVS1 & 8 & $\begin{array}{l}\text { A target site for integration of genome editing } \\
\text { technologies into the human genome (Not a disease } \\
\text { associated gene) [21-24] }\end{array}$ \\
\hline EGFR & 7 & Cancer $[25,26]$ \\
\hline CFTR & 6 & Cystic Fibrosis $[27,11,12]$ \\
\hline mTOR & 6 & Cancer $[28,29]$ \\
\hline b-Catenin & 6 & Cancer [30-32] \\
\hline CD34 & 5 & $\begin{array}{l}\text { CD34+ hematopoietic stem cells are targets for genome } \\
\text { editing for treatment of hemoglobinopathies [15] }\end{array}$ \\
\hline CXCR4 & 5 & HIV/AIDS $[14,13]$ \\
\hline HBB & 4 & Sickle Cell Anemia, thalassemia, malaria $[33-35,16,15]$ \\
\hline
\end{tabular}

Interestingly, malaria, a disease that predominantly affects sub-saharan Africa is one of the top diseases for CRISPR research although researchers from the region are heavily underrepresented in the field. While Africa is underrepresented in several areas of research besides genome editing, underrepresentation in genome editing is crucial as the technology has a great potential in malaria eradication but also poses broader ethical issues [36, 37].

An understanding of species that are research targets of genome editing technologies could help identify neglected species by the emerging technology. Therefore, we extracted words referring to various species from the abstracts. Among the top species of interest in genome editing research using CRISPR, humans were the most common (519 articles), followed by mice (306), yeast (S. cerevisiae, 76), zebrafish (60), rice (40), pigs (34), drosophila (32), HIV (28), and Caenorhabditis elegans (27). Similarly, for TALENs, human cells were the most commonly studied (38 articles), mice (22), zebrafish (10), rat (10), pigs (9), rice (5) and wheat (5).

\section{Discussion}

Genome editing technologies could revolutionize treatment of several diseases and open new ways for engineering biological organisms for medical and non-medical applications. An understanding of the global distribution of genome editing research could inform policy development, funding strategies and identify research biases that could lead to disparities in the application of the technology. Unfortunately, with thousands of papers being published in the field, manual curation of their content is not optimal. Automated approaches to mining literature could fill this gap 
by providing an unbiased and rapid assessment of progress in the field. However, there are several drawbacks to applying automated literature-mining approaches. First, mining of published literature cannot capture all research. For example, proprietary research in commercial companies is often not published. Furthermore, even in academia, research may not always be published immediately. Secondly, many publications are behind paywalls thereby limiting literature mining to only abstracts. Finally, computational approaches for mining text using natural language processing (NLP) and machine learning are still not able to cope with the complexity ambiguity and diversity of human language.

In this work, literature mining of genome editing publications shows that the development of the technology disproportionately occurs in the US and China. While the US leads in CRISPR based studies, China leads in TALENs. Thus, these two nations may potentially be the first to see significant benefits of genome editing technologies. While today no clinical applications have been approved for genome editing technologies, the technology could provide early economic benefits such as new careers especially for the researchers needed to develop the technology. It is conceivable that regions of the world already leading research in this area will be well positioned with the human capacity required to advance it which will result in disproportionate economic gains. Regions of the world such as Africa that are underrepresented in research in this field will left behind and may not be able to catch up.

Genome editing research is not immune to entrenched biases that exist in our society today. In particular, gender biases in science and technology could bias the development of genome editing technologies. However, the relatively recent emergence of the field compared to other areas of technology provides a unique window of opportunity that should be used to avoid new biases and address those inherited from related fields. The results presented in this work show that while there are $60 \%$ male and $40 \%$ female researchers in this field based on publications, the principal investigators are predominantly male (76\%) which is consistent with observations that women are even more underrepresented in leadership roles in Science, Technology, Engineering, Mathematics and Medicine (STEMM) fields [38].

The disproportionate development of genome editing technologies towards a select number of diseases, genes and animals or plants is also notable. It is encouraging that among the top diseases where genome editing research is ongoing are rare diseases such as Duchenne Muscular Dystrophy [19] and those that predominantly afflict some of the poorest regions of the world such as malaria [37, 39]. Unfortunately, in the case of malaria, researchers based in areas affected by the disease (sub-Saharan Africa) are highly underrepresented in genome editing research. This misalignment needs to be addressed because objective assessment of the safety, ethical and economic issues arising from genome editing technologies will require regulatory approvals by local experts and will directly impact local communities. Furthermore, a significant number of genome editing publications are in subscription journals and may be inaccessible to researchers in poorer regions of 
the world making it harder for them to compete in the field. Proactive engagement of researchers in areas where field applications such as mosquito gene drives will be deployed occur using genome editing technologies will be crucial [36]. One such partnership is the Target Malaria consortium that brings together various stakeholders including researchers and risk-assessment specialists from Europe and Africa [40].

Genome editing is a powerful technology. Its disproportionate development by a few researchers, regions of the world or in a gender-biased manner will limit its full potential. Furthermore, its disproportionate application to select genes, diseases and organisms could limit its capacity as an aid for deepening our understanding of basic biological processes across various organisms, engineering new biological systems for food or industrial purposes and eventually finding cures to several diseases.

\section{Materials and Methods}

\section{Data retrieval}

To download abstracts of publications on genome editing, the PubMed literature database was queried on May 21st 2018 using the 'easyPubMed' package in R. Briefly, the PubMed database was queried using 4 search queries independently, two for CRISPR/Cas based genome editing and two for TALENs based genome editing. To obtain genome editing publications involving CRISPR/Cas systems in 2017 the in the search term used was "CRISPR genome editing AND (2017[PDAT])" while to download genome editing publications involving CRISPR/Cas systems in 2018, the search term used was "CRISPR genome editing AND (2018[PDAT])". Abstracts on TALENs based genome editing were downloaded using the search terms "TALENs genome editing AND (2017[PDAT])" for publications in 2017 and "TALENs genome editing AND (2018[PDAT])" for publications in 2018. Because CRISPR research does not always involve genome editing, these numbers capture only the subset of papers where the abstracts explicitly mention genome editing. Abstracts were downloaded in XML format to allow further retrieval of metadata such as author names, institutional affiliations, addresses and countries.

\section{Analysis of author names, gender and institutional affiliations}

Author names, journals and institutional addresses were directly extracted from the downloaded XML abstracts using the R package 'easyPubMed'. Authors were assigned a gender using data from the US Social Security Administration baby names as implemented in the $\mathrm{R}$ package 'gender'. Institutional addresses were further processed to identify country names using the R package 'map'. 
Named entity recognition to identify diseases, gene names and species

Extraction of named biomedical entities such as genes, diseases and species referred to in the downloaded abstracts was performed using the R package 'pubmed.mine. $R$ ' [41].

\section{References}

1. Kim J-S: Genome editing comes of age. Nat Protoc 2016, 11:1573-1578.

2. Carroll D: Genome editing: Progress and challenges for medical applications. Genome Medicine 2016.

3. Cox DBT, Platt RJ, Zhang F: Therapeutic genome editing: Prospects and challenges. Nature Medicine 2015:121-131.

4. Silva G, Poirot L, Galetto R, Smith J, Montoya G, Duchateau P, Paques F:

Meganucleases and Other Tools for Targeted Genome Engineering:

Perspectives and Challenges for Gene Therapy. Curr Gene Ther 2011, 11:11-27.

5. Urnov FD, Rebar EJ, Holmes MC, Zhang HS, Gregory PD: Genome editing with engineered zinc finger nucleases. Nat Rev Genet 2010, 11:636-646.

6. Wang H, La Russa M, Qi LS: CRISPR/Cas9 in Genome Editing and Beyond. Annu Rev Biochem 2016, 85:227-264.

7. Bendels MHK, Müller R, Brueggmann D, Groneberg DA: Gender disparities in high-quality research revealed by nature index journals. PLoS One 2018, 13. 8. Valantine HA, Collins FS: National Institutes of Health addresses the science of diversity. Proc Natl Acad Sci 2015, 112:12240-12242.

9. Sergiu C, Diana G, Amin H, Ioana BN: Restoring the p53 “Guardian” Phenotype in p53-Deficient Tumor Cells with CRISPR/Cas9. Trends in Biotechnology 2018. 10. Ananiev J, Tchernev G, Patterson JW, Gulubova M, Ganchev G: p53 - "The Guardian of Genome." Acta Medica Bulgarica 2011:72-82.

11. Mall MA, Hartl D: CFTR: Cystic fibrosis and beyond. Eur Respir J 2014, 44:1042-1054.

12. Xu Q, Hou Y xian, Chang X bao: CRISPR/Cas9-Mediated Three Nucleotide Insertion Corrects a Deletion Mutation in MRP1/ABCC1 and Restores Its Proper Folding and Function. Mol Ther - Nucleic Acids 2017, 7:429-438.

13. Hou P, Chen S, Wang S, Yu X, Chen Y, Jiang M, Zhuang K, Ho W, Hou W, Huang J, Guo D: Genome editing of CXCR4 by CRISPR/cas9 confers cells resistant to HIV1 infection. Sci Rep 2015, 5:15577.

14. Bleul CC, Wu L, Hoxie JA, Springer TA, Mackay CR: The HIV coreceptors CXCR4 and CCR5 are differentially expressed and regulated on human Tymphocytes. Proc Natl Acad Sci 1997, 94:1925-1930.

15. Dever DP, Bak RO, Reinisch A, Camarena J, Washington G, Nicolas CE, Pavel-Dinu M, Saxena N, Wilkens AB, Mantri S, Uchida N, Hendel A, Narla A, Majeti R, Weinberg KI, Porteus MH: CRISPR/Cas9 $\beta$-globin gene targeting in human haematopoietic stem cells. Nature 2016, 539:384-389.

16. Tasan I, Jain S, Zhao H: Use of genome-editing tools to treat sickle cell disease. Human Genetics 2016:1011-1028.

17. Douek DC, Brenchley JM, Betts MR, Ambrozak DR, Hill BJ, Okamoto Y, Casazza JP, 
Kuruppu J, Kunstman K, Wolinsky S, Grossman Z, Dybul M, Oxenius A, Price DA, Connors M, Koup RA: HIV preferentially infects HIV-specific CD4+T cells. Nature 2002, 417:95-98.

18. England SB, Nicholson LVB, Johnson MA, Forrest SM, Love DR, Zubrzycka-Gaarn EE, Bulman DE, Harris JB, Davies KE: Very mild muscular dystrophy associated with the deletion of $\mathbf{4 6 \%}$ of dystrophin. Nature 1990, 343:180-182.

19. Xu L, Park KH, Zhao L, Xu J, El Refaey M, Gao Y, Zhu H, Ma J, Han R: CRISPRmediated genome editing restores dystrophin expression and function in $\mathbf{m d x}$ mice. Mol Ther 2016, 24:564-569.

20. Lane DP: Cancer. p53, guardian of the genome. Nature 1992:15-16.

21. Ward $P$, Walsh CE: Targeted integration of a rAAV vector into the AAVS1 region. Virology 2012, 433:356-366.

22. Oceguera-Yanez F, Kim S Il, Matsumoto T, Tan GW, Xiang L, Hatani T, Kondo T, Ikeya M, Yoshida Y, Inoue H, Woltjen K: Engineering the AAVS1 locus for consistent and scalable transgene expression in human iPSCs and their differentiated derivatives. Methods 2016, 101:43-55.

23. Ogata T, Kozuka T, Kanda T: Identification of an insulator in AAVS1, a preferred region for integration of adeno-associated virus DNA. J Virol 2003, 77:9000-7.

24. Kotin RM, Linden RM, Berns KI: Characterization of a preferred site on human chromosome 19q for integration of adeno-associated virus DNA by non-homologous recombination. EMBO J 1992, 11:5071-8.

25. Normanno N, De Luca A, Bianco C, Strizzi L, Mancino M, Maiello MR, Carotenuto A, De Feo G, Caponigro F, Salomon DS: Epidermal growth factor receptor (EGFR) signaling in cancer. Gene 2006:2-16.

26. Park M-Y, Jung MH, Eo EY, Kim S, Lee SH, Lee YJ, Park JS, Cho YJ, Chung JH, Kim $\mathrm{CH}$, Yoon $\mathrm{H}$ Il, Lee JH, Lee C-T: Generation of lung cancer cell lines harboring EGFR T790M mutation by CRISPR/Cas9-mediated genome editing. Oncotarget 2017, 8:36331-36338.

27. Greger R, Schreiber R, Mall M, Wissner A, Hopf A, Briel M, Bleich M, Warth R, Kunzelmann K: Cystic fibrosis and CFTR. In Pflugers Archiv European Journal of Physiology. Volume 443; 2001(SUPPL. 1).

28. Guertin DA, Sabatini DM: Defining the Role of mTOR in Cancer. Cancer Cell 2007:9-22.

29. Laplante M, Sabatini DM: MTOR signaling in growth control and disease. Cell 2012:274-293.

30. Barker N: The Canonical Wnt/b-Catenin Signalling Pathway. In Wnt

Signaling, Volume I: Pathway Methods and Mammalian Models. Volume 468; 2008:515.

31. Morin PJ, Sparks AB, Korinek V, Barker N, Clevers H, Vogelstein B, Kinzler KW: Activation of b-catenin-Tcf signaling in colon cancer by mutations in b-catenin or APC. Science (80-) 1997, 275:1787-1790.

32. Guan L, Zhu S, Han Y, Yang C, Liu Y, Qiao L, Li X, Li H, Lin J: Knockout of CTNNB1 by CRISPR-Cas 9 technology inhibits cell proliferation through the Wnt/ $\beta$ catenin signaling pathway. Biotechnol Lett 2018, 40:501-508.

33. Gouagna LC, Bancone G, Yao F, Yameogo B, Dabiré KR, Costantini C, Simporé J, 
Ouedraogo JB, Modiano D: Genetic variation in human HBB is associated with Plasmodium falciparum transmission. Nat Genet 2010, 42:328-331.

34. Cao A, Galanello R: Beta-thalassemia. Genetics in Medicine 2010:61-76.

35. Seltzer WK, Abshire TC, Lane PA, Roloff JS, Githed JH: Molecular genetic studies in black families with sickle cell anemia and unusually high levels of fetal hemoglobin. Hemoglobin 1992, 16:363-377.

36. Najjar DA, Normandin AM, Strait EA, Esvelt KM: Driving towards ecotechnologies. Pathogens and Global Health 2018:1-11.

37. Raban R, Akbari OS: Gene drives may be the next step towards sustainable control of malaria. Pathogens and Global Health 2017:1-2.

38. Rexrode KM: The gender gap in first authorship of research papers. $B M J$ 2016:i1130.

39. Li M, Bui M, Yang T, Bowman CS, White BJ, Akbari OS: Germline Cas9 expression yields highly efficient genome engineering in a major worldwide disease vector, Aedes aegypti. Proc Natl Acad Sci 2017:201711538.

40. Banks J: Target Malaria Has a Killer in Its Sights: Eliminating the world?s deadliest disease has been a priority for decades, and, thanks to innovative gene-drive technology, Target Malaria is getting closer to achieving that goal. IEEE Pulse 2016, 7:30-33.

41. Zhang Y, Sarkar IN, Chen ES: PubMedMiner: Mining and Visualizing MeSHbased Associations in PubMed. AMIA Annu Symp Proc 2014, 2014:1990-9.

\section{Supplementary Materials}

Supplementary Table 1: Number of articles per journal in the top 50 journals for CRISPR genome editing in 2017.

\begin{tabular}{|l|l|}
\hline Journal Name & $\begin{array}{l}\text { Number of } \\
\text { articles }\end{array}$ \\
\hline Sci Rep & 81 \\
\hline Methods Mol. Biol. & 49 \\
\hline Nat Commun & 32 \\
\hline Nature & 30 \\
\hline PLoS ONE & 27 \\
\hline Proc. Natl. Acad. Sci. U.S.A. & 22 \\
\hline Front Plant Sci & 21 \\
\hline ACS Synth Biol & 18 \\
\hline Mol. Cell & 18 \\
\hline Nat. Biotechnol. & 18 \\
\hline Nucleic Acids Res. & 18 \\
\hline Plant Biotechnol. J. & 18 \\
\hline Prog Mol Biol Transl Sci & 18 \\
\hline Mol Ther Nucleic Acids & 17 \\
\hline Oncotarget & 17 \\
\hline
\end{tabular}




\begin{tabular}{|c|c|}
\hline Methods & 15 \\
\hline Sheng Wu Gong Cheng Xue Bao & 15 \\
\hline Mol. Ther. & 14 \\
\hline Adv. Exp. Med. Biol. & 13 \\
\hline Science & 13 \\
\hline Sci China Life Sci & 12 \\
\hline Mamm. Genome & 11 \\
\hline ACS Chem. Biol. & 10 \\
\hline Int J Mol Sci & 10 \\
\hline Yale J Biol Med & 10 \\
\hline Cell & 9 \\
\hline Circ. Res. & 9 \\
\hline G3 (Bethesda) & 9 \\
\hline J Genet Genomics & 9 \\
\hline J. Biotechnol. & 9 \\
\hline J. Cell. Biochem. & 9 \\
\hline Stem Cell Reports & 9 \\
\hline Cell Rep & 8 \\
\hline Crit. Rev. Biotechnol. & 8 \\
\hline Dev. Biol. & 8 \\
\hline Elife & 8 \\
\hline Genome Biol. & 8 \\
\hline J Vis Exp & 8 \\
\hline mSphere & 8 \\
\hline Plant Cell Rep. & 8 \\
\hline Stem Cell Res & 8 \\
\hline Transgenic Res. & 8 \\
\hline Bio Protoc & 7 \\
\hline Biotechnol. Bioeng. & 7 \\
\hline Brief Funct Genomics & 7 \\
\hline Cell Stem Cell & 7 \\
\hline Curr Issues Mol Biol & 7 \\
\hline Microb. Cell Fact. & 7 \\
\hline Mol Plant & 7 \\
\hline Mol. Biol. Cell & 7 \\
\hline PLoS Genet. & 7 \\
\hline Protein Cell & 7 \\
\hline
\end{tabular}


Supplementary Table 2: Number of articles per journal in the top journals for TALENs genome editing in 2017.

\begin{tabular}{|l|l|}
\hline Journal Name & Number of Papers \\
\hline Methods Mol. Biol. & 12 \\
\hline Front Plant Sci & 6 \\
\hline PLoS ONE & 5 \\
\hline Dev. Biol. & 4 \\
\hline Mol Ther Methods Clin Dev & 4 \\
\hline Prog Mol Biol Transl Sci & 4 \\
\hline Crit. Rev. Biotechnol. & 3 \\
\hline Hum. Gene Ther. & 3 \\
\hline ACS Synth Biol & 2 \\
\hline Cell Biosci & 2 \\
\hline Cell. Mol. Life Sci. & 2 \\
\hline Front Mol Neurosci & 2 \\
\hline J. Biotechnol. & 2 \\
\hline Nat Protoc & 2 \\
\hline Nucleic Acids Res. & 2 \\
\hline Sci China Life Sci & 2 \\
\hline Sci Rep & 2 \\
\hline Sheng Wu Gong Cheng Xue Bao & 2 \\
\hline & \\
\hline
\end{tabular}

Supplementary Table 3: Author names and publication count for the top 50 authors for CRISPR (2017).

\begin{tabular}{|l|l|l|}
\hline Name & $\begin{array}{l}\text { Number of } \\
\text { Papers }\end{array}$ & Institutions \\
\hline Kim Jin-Soo & 15 & $\begin{array}{l}\text { Department of Chemistry, Seoul National University, Seoul, 151-747, } \\
\text { South Korea }\end{array}$ \\
\hline Zhang Feng & 15 & $\begin{array}{l}\text { Broad Institute of MIT and Harvard, Cambridge, MA 02142, USA; } \\
\text { McGovern Institute for Brain Research, Massachusetts Institute of } \\
\text { Technology, Cambridge, MA 02139, USA; }\end{array}$ \\
\hline Gao Caixia & 11 & $\begin{array}{l}\text { State Key Laboratory of Plant Cell and Chromosome Engineering, } \\
\text { Center for Genome Editing, Institute of Genetics and Developmental } \\
\text { Biology, Chinese Academy of Sciences, Beijing, China }\end{array}$ \\
\hline $\begin{array}{l}\text { Doudna } \\
\text { Jennifer A }\end{array}$ & 9 & $\begin{array}{l}\text { Department of Molecular and Cell Biology, University of California, } \\
\text { Berkeley, Berkeley, CA 94720, USA }\end{array}$ \\
\hline $\begin{array}{l}\text { Gersbach } \\
\text { Charles A }\end{array}$ & 9 & $\begin{array}{l}\text { Department of Biomedical Engineering, Duke University, Durham, NC } \\
\text { 27708, USA; }\end{array}$ \\
\hline $\begin{array}{l}\text { Musunuru } \\
\text { Kiran }\end{array}$ & 9 & $\begin{array}{l}\text { Department of Medicine \& Department of Genetics, Cardiovascular } \\
\text { Institute, Perelman School of Medicine at the University of } \\
\text { Pennsylvania, Philadelphia, PA 19104, USA. }\end{array}$ \\
\hline $\begin{array}{l}\text { Yamamoto } \\
\text { Takashi }\end{array}$ & 8 & $\begin{array}{l}\text { Department of Mathematical and Life Sciences, Graduate School of } \\
\text { Science, Hiroshima University, Higashi-Hiroshima, Hiroshima, Japan. }\end{array}$ \\
\hline
\end{tabular}




\begin{tabular}{|c|c|c|}
\hline $\begin{array}{l}\text { Gootenberg } \\
\text { Jonathan S }\end{array}$ & 7 & $\begin{array}{l}\text { Broad Institute of the Massachusetts Institute of Technology (MIT) } \\
\text { and Harvard, Cambridge, MA 02142, USA. }\end{array}$ \\
\hline $\begin{array}{l}\text { Mahfouz } \\
\text { Magdy M }\end{array}$ & 7 & $\begin{array}{l}\text { Laboratory for Genome Engineering, King Abdullah University of } \\
\text { Science and Technology (KAUST), Building \#2, Office 3232, } 4700 \\
\text { KAUST, Thuwal 23955-6900, Saudia Arabia. }\end{array}$ \\
\hline Yang Hui & 7 & $\begin{array}{l}\text { Institute of Neuroscience, State Key Laboratory of Neuroscience, Key } \\
\text { Laboratory of Primate Neurobiology, CAS Center for Excellence in } \\
\text { Brain Science and Intelligence Technology, Shanghai Institutes for } \\
\text { Biological Sciences, Chinese Academy of Sciences }\end{array}$ \\
\hline $\begin{array}{l}\text { Barrangou } \\
\text { Rodolphe }\end{array}$ & 6 & $\begin{array}{l}\text { Department of Food, Processing and Nutritional Sciences, North } \\
\text { Carolina State University, NC, United States. }\end{array}$ \\
\hline Corn Jacob E & 6 & $\begin{array}{l}\text { Innovative Genomics Institute, University of California, Berkeley, CA, } \\
\text { United States }\end{array}$ \\
\hline Kim Daesik & 6 & $\begin{array}{l}\text { Department of Chemistry, Seoul National University, Seoul, South } \\
\text { Korea. }\end{array}$ \\
\hline $\begin{array}{l}\text { Ledford } \\
\text { Heidi }\end{array}$ & 6 & University of California, Berkeley \\
\hline Li Wei & 6 & $\begin{array}{l}\text { Department of Plant Science and Landscape Architecture, University } \\
\text { of Connecticut, Storrs, CT USA. }\end{array}$ \\
\hline $\begin{array}{l}\text { Nureki } \\
\text { Osamu }\end{array}$ & 6 & $\begin{array}{l}\text { Department of Biological Sciences, Graduate School of Science, The } \\
\text { University of Tokyo, Tokyo, Japan }\end{array}$ \\
\hline $\begin{array}{l}\text { Puchta } \\
\text { Holger }\end{array}$ & 6 & $\begin{array}{l}\text { Botanical Institute, Karlsruhe Institute of Technology, POB 6980, } \\
\text { 76049, Karlsruhe, Germany }\end{array}$ \\
\hline $\begin{array}{l}\text { van der Oost } \\
\text { John }\end{array}$ & 6 & $\begin{array}{l}\text { Laboratory of Microbiology, Department of Agrotechnology and Food } \\
\text { Sciences, Wageningen University, Wageningen, Netherlands. }\end{array}$ \\
\hline $\begin{array}{l}\text { Voytas } \\
\text { Daniel F }\end{array}$ & 6 & $\begin{array}{l}\text { Department of Genetics, Cell Biology, and Development, Center for } \\
\text { Genome Engineering, University of Minnesota, Saint Paul, MN, 55108, } \\
\text { USA. }\end{array}$ \\
\hline Yang Fan & 6 & $\begin{array}{l}\text { Institute of Public Health, Guangzhou Institutes of Biomedicine and } \\
\text { Health, Chinese Academy of Sciences, Guangzhou, China }\end{array}$ \\
\hline Zhang Tao & 6 & $\begin{array}{l}\text { National Key Laboratory of Crop Genetic Improvement, National } \\
\text { Center of Plant Gene Research (Wuhan), Huazhong Agricultural } \\
\text { University, Wuhan 430070, China. }\end{array}$ \\
\hline $\begin{array}{l}\text { Abudayyeh } \\
\text { Omar } 0\end{array}$ & 5 & $\begin{array}{l}\text { Broad Institute of MIT and Harvard, Cambridge, Massachusetts } \\
\text { 02142, USA }\end{array}$ \\
\hline $\begin{array}{l}\text { Anderson } \\
\text { Daniel G }\end{array}$ & 5 & $\begin{array}{l}\text { David H. Koch Institute for Integrative Cancer Research, } \\
\text { Massachusetts Institute of Technology, Cambridge, Massachusetts, } \\
\text { USA. }\end{array}$ \\
\hline Bao Gang & 5 & $\begin{array}{l}\text { Department of Bioengineering, Rice University, HoustonTX, United } \\
\text { States. }\end{array}$ \\
\hline $\begin{array}{l}\text { Church } \\
\text { George M }\end{array}$ & 5 & $\begin{array}{l}\text { Wyss Institute for Biologically Inspired Engineering at Harvard } \\
\text { University, Boston, Massachusetts, USA. }\end{array}$ \\
\hline Gu Feng & 5 & $\begin{array}{l}\text { State Key Laboratory of Ophthalmology and Optometry, School of } \\
\text { Ophthalmology and Optometry, Wenzhou Medical University, } \\
\text { Wenzhou 325000, Zhejiang, China }\end{array}$ \\
\hline Lee Ciaran M & 5 & $\begin{array}{l}\text { Department of Bioengineering, Rice University , Houston, Texas } \\
77005 \text {, United States }\end{array}$ \\
\hline Li Yin-Xiong & 5 & $\begin{array}{l}\text { Institute of Public Health, Guangzhou Institutes of Biomedicine and } \\
\text { Health, Chinese Academy of Sciences, Guangzhou, China }\end{array}$ \\
\hline Liu Qi & 5 & $\begin{array}{l}\text { Shanghai Tenth People's Hospital, Department of Bioinformatics, } \\
\text { School of Life Sciences and Technology, Tongji University, Shanghai } \\
\text { 200092, China }\end{array}$ \\
\hline Liu Yanli & 5 & $\begin{array}{l}\text { Institute of Public Health, Guangzhou Institutes of Biomedicine and } \\
\text { Health, Chinese Academy of Sciences, Guangzhou, China }\end{array}$ \\
\hline
\end{tabular}




\begin{tabular}{|c|c|c|}
\hline $\begin{array}{l}\text { Ohtsuka } \\
\text { Masato }\end{array}$ & 5 & $\begin{array}{l}\text { Department of Molecular Life Science, Division of Basic Medical } \\
\text { Science and Molecular Medicine, School of Medicine, Tokai } \\
\text { University, Kanagawa, Japan }\end{array}$ \\
\hline Qi Yiping & 5 & $\begin{array}{l}\text { Department of Biology, East Carolina University, Greenville, NC } \\
\text { 27858, USA }\end{array}$ \\
\hline $\begin{array}{l}\text { Sakuma } \\
\text { Tetsushi }\end{array}$ & 5 & $\begin{array}{l}\text { Department of Mathematical and Life Sciences, Graduate School of } \\
\text { Science, Hiroshima University, Higashi-Hiroshima, Hiroshima, Japan }\end{array}$ \\
\hline $\begin{array}{l}\text { Tsang } \\
\text { Stephen } \mathrm{H}\end{array}$ & 5 & $\begin{array}{l}\text { Jonas Children's Vision Care and Bernard and Shirlee Brown } \\
\text { Glaucoma Laboratory, Columbia Stem Cell Initiative, Departments of } \\
\text { Ophthalmology, Pathology and Cell Biology, Institute of Human } \\
\text { Nutrition, College of Physicians and Surgeons, Columbia University, } \\
\text { New York, New York, USA }\end{array}$ \\
\hline Wang Haoyi & 5 & $\begin{array}{l}\text { State Key Laboratory of Stem Cell and Reproductive Biology, Institute } \\
\text { of Zoology, Chinese Academy of Sciences, Beijing 100190, China }\end{array}$ \\
\hline Wang Kejian & 5 & $\begin{array}{l}\text { State Key Laboratory of Rice Biology, China National Rice Research } \\
\text { Institute, Chinese Academy of Agricultural Sciences, Hangzhou, } \\
\text { 310006, China }\end{array}$ \\
\hline Wei Yu & 5 & $\begin{array}{l}\text { Shanghai Key Laboratory of Regulatory Biology, School of Life } \\
\text { Sciences, East China Normal University, Shanghai 200241, China }\end{array}$ \\
\hline Wu Jun & 5 & $\begin{array}{l}\text { Salk Institute for Biological Studies, } 10010 \text { N. Torrey Pines Rd., La } \\
\text { Jolla, CA, 92037, USA }\end{array}$ \\
\hline Xie Kabin & 5 & $\begin{array}{l}\text { National Key Laboratory of Crop Genetic Improvement and National } \\
\text { Centre of Plant Gene Research (Wuhan), Huazhong Agricultural } \\
\text { University, Wuhan } 430070 \text {, China }\end{array}$ \\
\hline Xu Han & 5 & $\begin{array}{l}\text { Cell and Gene Therapy Unit, Amgen Inc. } 1120 \text { Veterans Boulevard, } \\
\text { South San Francisco, CA, USA }\end{array}$ \\
\hline Yang Bing & 5 & Iowa State University, Ames, IA, United States \\
\hline Zhao Yunde & 5 & $\begin{array}{l}\text { National Key Laboratory of Crop Genetic Improvement and National } \\
\text { Center of Plant Gene Research (Wuhan), Huazhong Agricultural } \\
\text { University, Wuhan 430070, China }\end{array}$ \\
\hline $\begin{array}{l}\text { Zhu Jian- } \\
\text { Kang }\end{array}$ & 5 & $\begin{array}{l}\text { Shanghai Center for Plant Stress Biology and Center for Excellence in } \\
\text { Molecular Plant Sciences, Chinese Academy of Sciences, } 201602 \\
\text { Shanghai, China }\end{array}$ \\
\hline $\begin{array}{l}\text { Bauer Daniel } \\
\text { E }\end{array}$ & 4 & $\begin{array}{l}\text { Division of Hematology/Oncology, Boston Children's Hospital, } \\
\text { Boston, Massachusetts, USA }\end{array}$ \\
\hline $\begin{array}{l}\text { Brunger } \\
\text { Jonathan M }\end{array}$ & 4 & Duke University, Durham, North Carolina \\
\hline $\begin{array}{l}\text { Chadwick } \\
\text { Alexandra C }\end{array}$ & 4 & $\begin{array}{l}\text { Department of Medicine and Department of Genetics, Cardiovascular } \\
\text { Institute, Perelman School of Medicine at the University of } \\
\text { Pennsylvania, Philadelphia }\end{array}$ \\
\hline Chen Jia & 4 & $\begin{array}{l}\text { School of Life Science and Technology, ShanghaiTech University, } \\
\text { Shanghai, China }\end{array}$ \\
\hline Chen Wei & 4 & $\begin{array}{l}\text { State Key Laboratory of Food Science and Technology, Jiangnan } \\
\text { University, Wuxi, Jiangsu, 214122, China. }\end{array}$ \\
\hline Gao Ge & 4 & $\begin{array}{l}\text { Institute of Public Health, Guangzhou Institutes of Biomedicine and } \\
\text { Health, Chinese Academy of Sciences, Guangzhou, China }\end{array}$ \\
\hline $\begin{array}{l}\text { Guilak } \\
\text { Farshid }\end{array}$ & 4 & $\begin{array}{l}\text { Department of Orthopedic Surgery, Washington University, St. Louis, } \\
\text { MO 63110, USA; Shriners Hospitals for Children - St. Louis, St. Louis, } \\
\text { MO 63110, USA }\end{array}$ \\
\hline
\end{tabular}


Supplementary Table 4: Author names and publication count for the top 50 authors for TALENs (2017).

\begin{tabular}{|c|c|c|}
\hline Names & $\begin{array}{l}\text { Number of } \\
\text { Papers }\end{array}$ & Institution \\
\hline $\begin{array}{l}\text { Sakuma } \\
\text { Tetsushi }\end{array}$ & 5 & $\begin{array}{l}\text { Department of Mathematical and Life Sciences, Graduate School of } \\
\text { Science, Hiroshima University, Hiroshima, Japan }\end{array}$ \\
\hline $\begin{array}{l}\text { Yamamoto } \\
\text { Takashi }\end{array}$ & 5 & $\begin{array}{l}\text { Department of Mathematical and Life Sciences, Graduate School of } \\
\text { Science, Hiroshima University, Hiroshima, Japan }\end{array}$ \\
\hline $\begin{array}{l}\text { Cathomen } \\
\text { Toni }\end{array}$ & 4 & $\begin{array}{l}\text { Institute for Transfusion Medicine and Gene Therapy, Medical } \\
\text { Center- University of Freiburg, Freiburg, Germany; Faculty of } \\
\text { Medicine, University of Freiburg, Freiburg, Germany. }\end{array}$ \\
\hline $\begin{array}{l}\text { Mussolino } \\
\text { Claudio }\end{array}$ & 4 & $\begin{array}{l}\text { Institute for Cell and Gene Therapy, University Medical Center } \\
\text { Freiburg, Freiburg, Germany }\end{array}$ \\
\hline Alzubi Jamal & 2 & $\begin{array}{l}\text { Institute for Transfusion Medicine and Gene Therapy, Medical } \\
\text { Center - University of Freiburg, Freiburg, Germany }\end{array}$ \\
\hline Bortesi Luisa & 2 & $\begin{array}{l}\text { Institute for Molecular Biotechnology, RWTH Aachen University, } \\
\text { Worringerweg 1, } 52074 \text { Aachen, Germany }\end{array}$ \\
\hline $\begin{array}{l}\text { Fischer } \\
\text { Rainer }\end{array}$ & 2 & $\begin{array}{l}\text { Institute for Molecular Biotechnology, RWTH Aachen University, } \\
\text { Worringerweg 1, } 52074 \text { Aachen, Germany }\end{array}$ \\
\hline $\begin{array}{l}\text { Germini } \\
\text { Diego }\end{array}$ & 2 & $\begin{array}{l}\text { UMR 8126, Université Paris Sud - Paris Saclay, CNRS, Institut } \\
\text { Gustave Roussy, } 94805 \text { Villejuif, France }\end{array}$ \\
\hline Gu Feng & 2 & $\begin{array}{l}\text { State Key Laboratory of Ophthalmology and Optometry, School of } \\
\text { Ophthalmology and Optometry, Wenzhou Medical University, } \\
\text { Wenzhou } 325000 \text {, Zhejiang, China }\end{array}$ \\
\hline He Xiubin & 2 & $\begin{array}{l}\text { State Key Laboratory of Ophthalmology, Optometry and Vision } \\
\text { Science, School of Ophthalmology and Optometry, Eye Hospital, } \\
\text { Wenzhou Medical University, Wenzhou, China }\end{array}$ \\
\hline Hendel Ayal & 2 & $\begin{array}{l}\text { The Mina and Everard Goodman Faculty of Life Sciences and } \\
\text { Advanced Materials and Nanotechnology Institute, Bar-Ilan } \\
\text { University, Ramat-Gan } 52900 \text { Israel }\end{array}$ \\
\hline $\begin{array}{l}\text { Horb Marko } \\
\text { E }\end{array}$ & 2 & $\begin{array}{l}\text { National Xenopus Resource and Eugene Bell Center for Regenerative } \\
\text { Biology and Tissue Engineering, Marine Biological Laboratory, } \\
\text { Woods Hole, MA 02543, United States }\end{array}$ \\
\hline $\begin{array}{l}\text { Kaneko } \\
\text { Takehito }\end{array}$ & 2 & $\begin{array}{l}\text { Institute of Laboratory Animals, Graduate School of Medicine, Kyoto } \\
\text { University, Kyoto 606-8501, Japan }\end{array}$ \\
\hline $\begin{array}{l}\text { Karakikes } \\
\text { Ioannis }\end{array}$ & 2 & $\begin{array}{l}\text { Stanford Cardiovascular Institute, Stanford University School of } \\
\text { Medicine, Stanford, CA, 94305, USA. ioannis1@stanford.edu }\end{array}$ \\
\hline Koller Ulrich & 2 & $\begin{array}{l}\text { EB House Austria, Research Program for Molecular Therapy of } \\
\text { Genodermatoses, Department of Dermatology, University Hospital of } \\
\text { the Paracelsus Medical University, Salzburg, Austria }\end{array}$ \\
\hline $\begin{array}{l}\text { Musunuru } \\
\text { Kiran }\end{array}$ & 2 & $\begin{array}{l}\text { Cardiovascular Institute, Department of Medicine, Perelman School } \\
\text { of Medicine at the University of Pennsylvania, Philadelphia, PA, USA }\end{array}$ \\
\hline Reichelt Julia & 2 & $\begin{array}{l}\text { EB House Austria, Research Program for Molecular Therapy of } \\
\text { Genodermatoses and Department of Dermatology, University } \\
\text { Hospital of the Paracelsus Medical University Salzburg, } 5020 \\
\text { Salzburg, Austria }\end{array}$ \\
\hline $\begin{array}{l}\text { Sasakura } \\
\text { Yasunori }\end{array}$ & 2 & $\begin{array}{l}\text { Shimoda Marine Research Center, University of Tsukuba, Shimoda, } \\
\text { Shizuoka 415-0025, Japan }\end{array}$ \\
\hline $\begin{array}{l}\text { Seeger } \\
\text { Timon }\end{array}$ & 2 & $\begin{array}{l}\text { Stanford Cardiovascular Institute, Stanford University School of } \\
\text { Medicine, Stanford, CA, 94305, USA. }\end{array}$ \\
\hline $\begin{array}{l}\text { Sjakste } \\
\text { Nikolajs }\end{array}$ & 2 & Faculty of Medicine, University of Latvia, Riga, Latvia. \\
\hline
\end{tabular}




\begin{tabular}{|l|l|l|}
\hline $\begin{array}{l}\text { Termglincha } \\
\text { n Vittavat }\end{array}$ & 2 & $\begin{array}{l}\text { Stanford Cardiovascular Institute, Stanford University School of } \\
\text { Medicine, Stanford, CA, 94305, USA }\end{array}$ \\
\hline $\begin{array}{l}\text { Thrasher } \\
\text { Adrian J }\end{array}$ & 2 & $\begin{array}{l}\text { Institute of Child Health, University College London, London, United } \\
\text { Kingdom }\end{array}$ \\
\hline $\begin{array}{l}\text { Treen } \\
\text { Nicholas }\end{array}$ & 2 & $\begin{array}{l}\text { Lewis-Sigler Institute for Integrative Genomics, Princeton University, } \\
\text { Princeton, NJ, USA }\end{array}$ \\
\hline $\begin{array}{l}\text { Tsfasman } \\
\text { Tatiana }\end{array}$ & 2 & $\begin{array}{l}\text { UMR 8126, Université Paris Sud - Paris Saclay, CNRS, Institut } \\
\text { Gustave Roussy, 94805 Villejuif, France }\end{array}$ \\
\hline $\begin{array}{l}\text { Vassetzky } \\
\text { Yegor }\end{array}$ & 2 & $\begin{array}{l}\text { UMR8126, Université Paris Sud - Paris Saclay, CNRS, Institut Gustave } \\
\text { Roussy, 94805 Villejuif, France }\end{array}$ \\
\hline $\begin{array}{l}\text { Wang Haoyi } \\
\text { State Key Laboratory of Stem Cell and Reproductive Biology, } \\
\text { Institute of Zoology, Chinese Academy of Sciences, Beijing 100101, } \\
\text { China }\end{array}$ \\
\hline Wu Joseph C & 2 & $\begin{array}{l}\text { Department of Medicine, Division of Cardiovascular Medicine, } \\
\text { Stanford University School of Medicine, Stanford, California 94305, } \\
\text { USA }\end{array}$ \\
\hline $\begin{array}{l}\text { Yoshida } \\
\text { Keita }\end{array}$ & 2 & $\begin{array}{l}\text { Shimoda Marine Research Center, University of Tsukuba, Shimoda, } \\
\text { Shizuoka, Japan }\end{array}$ \\
\hline
\end{tabular}

